\title{
Clinical Study Reports and Related Information
}

National Cancer Institute

\section{Source}

National Cancer Institute. Clinical Study Reports and Related Information. NCI Thesaurus. Code C79176.

Records related to clinical study reports. 